\title{
Ewelina Radion*
}

(iD) https://orcid.org/0000-0002-4252-3649

\section{Percepcja wrażeń akustycznych w wierszu Mochnacki Jana Lechonia}

Dotychczasowy stan badań nad sferą akustyczną utrwaloną w poezji Jana Lechonia wiąże się z interdyscyplinarnymi studiami nad „muzycznością” poezji, rozumianą jako pewien nieokreślony bliżej związek źródłowy między literaturą a muzyką, między estetyką literacką a muzyczną, między pewnymi aspektami dzieła literackiego a aspektami kompozycji muzycznej".

Badając „muzyczność” poezji Jana Lechonia, analizowano relacje słowa z muzyką na płaszczyźnie treściowej, wyobrażeniowej i fonicznej wierszy. Pisano o „koncercie polskości” Mochnackiego, zestawianym z koncertami z Pana Tadeusza i Koncertem Chopina Ort-Ota, o chopinowskim walcu granym przez panią Słowacką w Duchu na seansie, o postaci nadwornego lutnisty Zygmunta Augusta, zwanego Bekwarkiem i terytorium dźwiękowym zawartym w wierszu Lutnia po Bekwarku. Wskazywano na muzyczne odniesienia w Polonezie artyleryjskim, a także na relacje między Lechoniową Aria z kurantem a Strasznym dworem Stanisława Moniuszki oraz Marszem żałobnym z Sonaty b-moll Fryderyka Chopina. Zauważano obecne w wierszach nawiązania do śpiewów gregoriańskich (Męczennicy), piosenek żołnierskich (Marsz Drugiego Korpusu), Mazurka Dąbrowskiego (Przypowieść), czy Źródła Aretuzy - poematu na skrzypce i fortepian Karola Szymanowskiego (Niebo). Natomiast sprecyzowaniu warstwy dźwiękowej rzeczywistości lirycznej w utworze Mochnacki służy wielowątkowy namysł nad problemem: Czy Maurycy Mochnacki rzeczywiście koncertował w Metzu na klawikordzie?².

* Dr, Uniwersytet Rzeszowski, Wydział Filologiczny, Instytut Filologii Polskiej, al. mjr. W. Kopisto 2 B, 35-315 Rzeszów; e-mail: eradion@interia.pl

1 Por. A. Hejmej, Muzyczność dzieła literackiego, Wydawnictwo Uniwersytetu Wrocławskiego, Wrocław 2001, s. 53-67.

2 Zob. W. Horzyca, „Karmazynowy poemat”, „Skamander” 1920, z. 3, s. 159-170; J. Kwiatkowski, Czerwone i czarne. O poezji Jana Lechonia, w: tenże, Szkice do portretów, Państwowy Instytut 
Często przyjmowaną perspektywą badań nad „muzycznością” wierszy Lechonia jest jego biografia. Prześledzono artystyczne zainteresowania poety, muzyczne kompetencje oraz jego znajomości z artystami. Np. z klawesynistką - Wandą Landowską, której autor zadedykował wiersz Sarabanda, wybitnymi pianistami - Witoldem Małcużyńskim i Arturem Rubinsteinem oraz kompozytorem - Karolem Szymanowskim, będącym pierwowzorem postaci Kątskiego z nieukończonej powieści Bal u Senatora. Lechoń bardzo wysoko cenił twórczość autora Harnasi, czemu również dał wyraz w entuzjastycznej recenzji drukowanej w „Gazecie Polskiej” (1932), a kilka lat później, zabiegając o wystawienie baletu-pantomimy w Operze Paryskiej. Sporo uwagi poświęcono krytyce muzycznej Lechonia, szczególnie jego niezwykle trafnym sądom o muzyce Szymanowskiego. W licznych pracach o emigracyjnej działalności, o dziennikach, korespondencji i publicystyce radiowej autora Karmazynowego poematu wspominano również koncerty, w których Lechoń uczestniczył, jako słuchacz lub organizator.

Natomiast rozpatrując „muzyczność” wiersza Mochnacki wskazywano na poetycką wizję koncertu, z jakim Maurycy, bohater narodowy i artysta, wystąpił w 1832 roku w Metzu ${ }^{3}$. Literaturoznawcy i muzykolodzy niejednokrotnie podejmo-

Wydawniczy, Warszawa 1960, s. 5-209; I. Opacki, Od "Karmazynowego poematu” do "Wolności tragicznej". (Problematyka mitów narodowych w poezji Skamandra - zarys), w: Studia romantyczne, red. tenże, Uniwersytet Śląski, Katowice 1978, s. 5-36; I. Opacki, Dramat narodowej wyobraźni. Wokół „Karmazynowego poematu” Jana Lechonia, w: tenże, Poetyckie dialogi z kontekstem. Szkice o poezji XX wieku, „Śląsk”, Katowice 1979, s. 155-224; T. Burek, Wstęp, w: J. Lechoń, Poezje wybrane, wybór i wstęp T. Burek, Ludowa Spółdzielnia Wydawnicza, Warszawa 1990, s. 5-20; R. Loth, Wstęp, w: J. Lechoń, Poezje, Zakład Narodowy im. Ossolińskich, Wrocław 1990, s. III-XCIV; G. Ostasz, W cieniu "Herostratesa”. O tradycjach romantyzmu w poezji polskiej lat 1914-1939, Wydawnictwo WSP, Rzeszów 1994; J. Skarbowski, Muzyczna dusza Jana Lechonia, „ISME” 1995, nr 3-4, s. 71-80; G. Ostasz, Przypowieść Jana Lechonia, w: tenże, Przeciwko smokom, jadom, kulom... O poezji polskiej 1939-1945, Wydawnictwo WSP, Rzeszów 1998, s. 99-110; G. Ostasz, "Marsz Drugiego Korpusu” Jana Lechonia, czyli „Jeszcze Polska nie zginęła”, w: tenże, Filiacje, dialogi, spór z tradycją. Szkice o literaturze polskiej XX wieku, Wydawnictwo WSP, Rzeszów 2001, s. 65-79; J. Wiśniewski, Czy Maurycy Mochnacki koncertowat, grając na klawikordzie? Uwagi na marginesie wiersza Jana Lechonia, „Acta Universitatis Lodziensis. Folia Litteraria Polonica" 2001, z. 2, s. 41-46; D. Utracka, Emigracyjna wspólnota tęsknot, troski nadziei, czyli nad „koncertami polskości” - Mickiewicz - Lechoń - (szkic analityczno-porównawczy), w: Szczególne problemy człowieka i edukacji u progu XXI w. Księga jubileuszowa ofiarowana Profesorowi Bogdanowi Snochowi, red. S. Podobiński, Wydawnictwo WSP, Częstochowa 2002, s. 563-576; I. Chyła-Szypułowa, Muzyka w poezji Jana Lechonia, „Studia Artystyczne Akademii Świętokrzyskiej” 2007 , t. 4, s. 13-23; A. Kotliński, Polonez artyleryjski Jana Lechonia, w: Reinterpretacje, red. M. Tramer, A. Wójtowicz, Wydawnictwo Uniwersytetu Śląskiego, Katowice 2015, s. 151-165; G. Ostasz, Bekwark. Jana Lechonia osobowy znak sztuki idealnej, w: tenże, Śladami poezji czystej, Wydawnictwo Oświatowe Fosze, Rzeszów 2017, s. 39-52; E. Radion, Audiosfera "Karmazynowego poematu” Jana Lechonia, w: Literatura współczesna w edukacji polonistycznej. T. 2, Interpretacje - wartości - konteksty, red. U. Kopeć, Wydawnictwo Uniwersytetu Rzeszowskiego, Rzeszów 2017, s. 135-148. 
wali się interpretacji owych obrazów powstających pod wpływem słuchanej muzyki. Według Jerzego Skarbowskiego, w utworze tym

ześrodkowały się jak w soczewce wszystkie stosowane przez poetę środki mające na celu oddanie poprzez relację z koncertu pianisty poetyckiej historii epoki napoleońskiej i powstania listopadowego. Jest więc czynny uczestnik walk - Maurycy Mochnacki - równocześnie muzyk, rywal Chopina z Warszawy, są kirasjerzy, lite pasy, ogolone głowy. W toku wiersza występują określenia muzyczne - wioliny, basy, akordy, melodie - wprzęgnięte tutaj w służbę idei narodowych: wielkości Polski, uczuć patriotycznych ${ }^{4}$.

\section{Sound studies}

Kontekstem prowadzonych przeze mnie badań nad percepcją rzeczywistości fonicznej, prezentowanej w wierszu Mochnacki, są interdyscyplinarne badania nad dźwiękiem (sound studies), które związane są „z jak największą liczbą kontekstów w jakimkolwiek stopniu zdeterminowanych przez dźwięk czy słuchanie”. W W tym przypadku znaczące okazują się ustalenia muzykologów i krytyków muzycznych, zarówno działających na przełomie XIX i XX wieku, publikujących w okresie poprzedzającym ogłoszenie wiersza Mochnacki, jak i badaczy współczesnych, a także psychologów muzyki, rozważających, co najmniej od czasów powojennych, problem oddziaływania sztuki dźwięku na człowieka.

Istotne okazują się konkluzje psychoakustyków analizujących związki zachodzące między falą dźwiękową, docierającą do uszu słuchacza, a subiektywnie odczuwalnym wrażeniem, jakie u niego wywołuje ${ }^{6}$. Nie bez znaczenia - również dla analizy wiersza, będącego „udramatyzowanym obrazem muzycznego spektaklu” - jest fakt, że odbiór dźwięków zawsze zdeterminowany jest przez postrzeganie osobiste, właściwe dla każdego odbiorcy, budującemu użyteczny obraz rzeczywistości akustycznej z danych wchodzących do układu słuchowego ${ }^{8}$.

Tymczasem w dziele literackim odbiór dźwięków jest podwójnie subiektywny; po pierwsze, zdeterminowany przez indywidualność słuchacza, który przyswajając dźwięki, dokonuje selekcji, a po drugie, zależny od preferencji artysty, świadomości pisarza, którego dzieło zawsze jest wyrazem „jego subiektywnego

4 J. Skarbowski, dz. cyt., s. 79.

5 T. Misiak, W stronę kulturoznawczych badań nad dźwiękiem. Przypadek sound studies, „Muzyka” 2014, nr 1, s. 7-8.

6 Por. U. Jorasz, Wykłady z psychoakustyki, Wydawnictwo Naukowe UAM, Poznań 1998, s. 14.

7 D. Utracka, dz. cyt., s. 566.

8 Por. U. Jorasz, Selektywność układu słuchowego, Wydawnictwo Naukowe UAM, Poznań 1999, s. 63-65. 
widzenia świata, jego kompleksową estetyczną wypowiedzią o świecie"”. Warto przypomnieć, iż „utwór nigdy nie odnosi się do tych jedynie zdarzeń, rzeczy czy zjawisk, które stają się przed miotem przedstawienia lub wypowiedzi; wyraża przede wszystkim stosunek autora do rzeczywistości jako całości”"10.

W rozważaniach nad wrażeniami dźwiękowymi zawartymi w omawianym wierszu korzystam z obserwacji R. Murraya Schafera, twórcy ekologii akustycznej, kanadyjskiego kompozytora i pedagoga, który w centrum swoich rozważań postawił dźwięk „zaistniały w dowolnym miejscu i czasie, niezależnie od tego, czy jest to dźwięk muzyki, maszyny, człowieka, czy natury”"1. Postrzegam zarówno osobę mówiącą w wierszu Mochnacki, jak i samego Lechonia, w kategorii Schaferowskiego „nausznego świadka”"2 , werbalizującego swoje przeżycia w mowie wiązanej. Jako autora lirycznych opisów, wyrażających stosunek do zjawisk dźwiękowych. Jako pilnego badacza świata akustycznego, który spełnia wymagania jakie stawiał słuchaczom autor 100 ćwiczeń $w$ stuchaniu i tworzeniu muzyki $i^{13}$. Lechoń posiadał wrażliwość słuchową i świadomie korzystał ze zmysłu słuchu, co poświadczają jego utwory poetyckie. Potrafił właściwie odczytywać (identyfikować), rozpoznawać (interpretować) sygnały dźwiękowe, a przy tym - nieustannie aktualizować formułę pejzażu dźwiękowego, który ze swej natury jest żywy i ulega nieustannym zmianom. Nie bez racji Schafer traktował słuchacza zarówno jako odbiorcę, przyswajającego dźwięki, jak i twórcę, dokonującego wyboru, na które odgłosy zwróci swoją uwagę ${ }^{14}$. W koncepcji Schafera percepcja ma kluczowe znaczenie: „zarysowuje przestrzeń, dzieli rzeczywistość na znaną i nieznaną, na ograniczoną ramami percepcji i na nieograniczoną, pozostającą na zewnątrz"'

9 M. Grygar, Struktura prozy epickiej a jej stosunek do rzeczywistości, w: Styl i kompozycja. Konferencje teoretycznoliterackie w Toruniu i Ustroniu, red. J. Trzynadlowski, Zakład Narodowy im. Ossolińskich, Wrocław 1965, s. 189.

10 Tamże.

11 K. Marciniak, Trzydzieści lat ekologii akustycznej w Polsce, „Ruch Muzyczny” 2012, nr 18, s. 11-15. Na grunt języka polskiego definicje najważniejszych Schaferowskich terminów przełożyła Danuta Gwizdalanka (R. Murray Schafer, Muzyka środowiska, „Res Facta” 1982, nr 9, s. 288-315). W latach dziewięćdziesiątych XX wieku artykuły z zakresu ekologii akustycznej pojawiały się w czasopiśmie „Monochord”. Spory wpływ na upowszechnienie myśli kanadyjskiego kompozytora miał Maksymilian Kapelański, autor pracy magisterskiej: Koncepcja pejzażu dźwiękowego (soundscape) w pismach R. Murraya Schafera (1999).

12 K. Marciniak, Pejzaż dźwiękowy „Opisu obyczajów za panowania Augusta III” Jędrzeja Kitowicza, „Muzyka” 2014, nr 1, s. 25.

13 Zob. R.M. Schafer, The Thinking Ear. Complete Writings on Music Education, Arcana Editions, Toronto, 1986. Wydanie polskie: Poznaj dźwięk. 100 ćwiczeń w słuchaniu i tworzeniu muzyki, przeł. R. Augustyn, Brevis, Poznań 1995.

14 Por. R. Losiak, O opisach pejzaży dźwiękowych, „Prace Kulturoznawcze” 2010, t. 9, s. 224.

15 M. Gradowski, R. Murray Schafer - pan od przyrody?, „Glissando” 2004, nr 2, s. 27-35. 
Przechodząc na grunt rozpoznań literaturoznawczych, interesuje mnie więc taki rodzaj „muzyczności”, który objawia się, jako opis przedmiotu (dzieła muzycznego), albo jako opis perspektywy, gdzie centrum zorientowania przenosi się z samego dzieła muzycznego na perspektywę oglądu ${ }^{16}$. Taki rodzaj „muzyczności”, który uwidacznia się, gdy poezja „mówiąca” o sztuce „importuje na terytorium literatury pewne wartości naddane"17. Są nimi związane z utworem muzycznym przekonania autora, który nie podejmując się prób rekonstrukcji utworu muzycznego, postuluje raczej określony stosunek do sztuki, interweniuje w procesy percepcyjne, mówi o przebiegach odbiorczych, zajmuje się „swoistością muzycznego słyszenia”"18.

\section{Percepcja rzeczywistości akustycznej}

Od czasów starożytnych uznaje się, że percepcja jest procesem przetwarzania informacji przez zmysły, aby wytworzyć mentalny obraz świata. Słowo „percepcja” pochodzi od łacińskiego perceptio, co oznacza ujmowanie, uświadamianie sobie postrzeganych zjawisk ${ }^{19}$.

Proces percepcji wrażeń akustycznych jest reakcją układu nerwowego na bodźce. Neurony za pomocą połączenia nerwu ślimakowego z mózgiem przesyłają informacje słuchowe do mózgowych ośrodków słuchu, gdzie zostają następnie przekształcane na wrażenia dźwiękowe i wyobrażenia słuchowe ${ }^{20}$. To znaczy: na wrażenia, które wywołuje dźwięk rozumiany jako zjawisko fizyczne, posiadający określone cechy: wysokość, głośność, barwę i czas trwania, oraz na wyobrażenia słuchowe, opisywane jako „wewnętrzne obrazy słuchowe, aktywizujące się dowolnie bez udziału bodźca zewnętrznego, nie będące na ogół wierną kopią wcześniejszych spostrzeżeń lecz ich szczególnym przekształceniem”21. Zatem percepcja dźwięku to zarówno ujmowanie (identyfikacja), jak i uświadamianie sobie postrzeganych zjawisk (interpretacja).

Percepcja wrażeń akustycznych w wierszu Mochnacki obejmuje rozpoznawanie dobiegających z sali dźwięków, które - w wyniku dokonanej przez słuchacza selekcji - stały się częścią lirycznego opisu. Włączenie ich w ciąg relacjonowanych wydarzeń

16 A. Hejmej, dz. cyt., s. 78.

17 E. Balcerzan, Poezja jako semiotyka sztuki, w: Pogranicza i korespondencje sztuk. Studia, red. T. Cieślikowska, J. Sławiński, Wydawnictwo Instytutu Badań Literackich PAN, Wrocław 1980, s. 29.

18 Tamże, s. 34. O literackich przedstawieniach muzyki w wybranych utworach poetyckich pisał Jerzy Wiśniewski, Ku harmonii? Poetyckie style słuchania muzyki w wierszach polskich autorów po 1945 roku, Wydawnictwo Uniwersytetu Łódzkiego, Łódź 2013.

19 J. Wierszyłowski, Psychologia muzyki, Państwowe Wydawnictwo Naukowe, Warszawa 1979, S. 225 .

20 Za: P. Kładoczny, Semantyka nazw dźwięków w języku polskim. T 1, Leksem, Łask 2012, s. 21.

21 Za: tamże, s. 21-22. 
ujawnia, jak istotny dla osoby słuchającej koncertu Mochnackiego był kontakt między artystą a odbiorcami, a więc także każdy przejaw niechęci, który, niczym „okop hardy", uniemożliwia porozumienie. O właściwy kontakt z publicznością dbał również sam Lechoń, który, gdy recytował Mochnackiego, „na niezliczonych wieczorach poetyckich w Warszawie, budził za każdym razem taki sam dreszcz wśród słuchaczy, jak ten, co w wierszu «szedł po sali», słuchającej koncert w Metzu"22. Zarówno recital Mochnackiego, jak i deklamacja Lechonia przerażały, przejmowały lękiem. W wewnętrznym świecie poematu niepokój potęguje rewolucyjna pieśń, wieńcząca utwór, a podczas poetyckich wieczorów, na których poeta chętnie recytował Mochnackiego - owa zniewalająca siła, którą Stanisław Baliński porównał „z dynamizmem uczuciowym, jakim naładowana jest Etiuda rewolucyjna Chopina"23.

Niemniej jednak rzeczywistość wokół Mochnackiego, grającego na klawikordzie, nie jest precyzyjnie dookreślona. Otoczenie wyznaczają zwroty świadczące o powierzchowności oglądu: „a tam”, „a tu”, „a wyżej”. Wrażenia akustyczne „pochłaniają" słuchacza tak dalece, że zdaje się on tracić z oczu najbliższe otoczenie. Koncentrując się na odbiorze dźwięków, dba o to, ażeby nic nie wyprowadzało go „W sposób przykry ze świata muzyki, w którym wyłącznie się znajduje w czasie słuchania”" ${ }^{24}$. Następujące po sobie zespoły dźwiękowe prawdziwie go „poruszają", a więc stwarzają „impulsy motoryczne, czyli napięcia i pobudzenia ruchowe"25, które wprowadzają słuchacza w stan oczekiwania. Nie tylko osoba relacjonująca koncert Maurycego autentycznie "przeżywa muzykę", ale również kirasjer, który, jak czytamy w wierszu, „poruszył się w kącie”.

Podmiot słuchający z niezwykłą uwagą koncertu dokonuje analizy podstawowych cech dźwięku: wysokości, głośności, barwy i czasu trwania, które w muzyce odpowiadają następującym kategoriom: wysokości, dynamice, kolorystyce i uporządkowaniu rytmicznemu. Wtedy procesowi słuchania towarzyszą procesy analizy i syntezy materiału muzycznego, a "nauszny świadek” objawia się jako słuchacz analityczno-formalny, koncentrujący się na środkach kompozytorskich lub na cechach wykonania utworu ${ }^{26}$. Toteż odnotowuje kształt linii melodycznej („coraz niżej, niżej”, „więc do basu ucieka”, „wraca ku górze”). Zwraca uwagę na

22 J. Sakowski, Żałobny pas lity, w: S. Baliński i inni, Pamięci Jana Lechonia, Nakł. „Wiadomości”, Londyn 1958, s. 7.

23 S. Baliński, Lechoń - poeta, w: tamże, s. 60.

24 S. Szuman, O słuchaniu i przeżywaniu muzyki, w: tenże, Z. Lissa, Jak słuchać muzyki, Centralny Instytut Muzyki, Warszawa 1948, s. 16.

25 Tamże, s. 32.

26 W polskiej typologii, sporządzonej przez Janinę Koblewską-Wróblową, wyodrębniono pięć rodzajów słuchaczy: polisensorycznego, wyobrażeniowego, interpretującego, analityczno-formalnego, awersyjnego. Za: E. Szubertowska, Muzyczna aktywność własna a świadoma percepcja muzyki młodzieży szkół średnich, Wydawnictwo Akademii Bydgoskiej, Bydgoszcz 2002, s. 15-16. 
artykulację („plącze, zrywa tony”), tempo utworu („z wolna ją próbować akord po akordzie”), fakturę (akompaniament „szaleje”), dynamikę („raz, dwa, trzy, cztery - wali”, „tępo weń tłucze”, „uderzył w instrument”), harmonię („akord po akordzie”), tryb i rytmikę („równo, równo rosną w jakiś smutny taniec”). Reaguje na zmianę barwy przypisując dźwiękom - zgodnie z metodą semantycznego opisu barwy - konkretny zespół parametrów określany za pomocą określeń werbalnych, tzn. przymiotników („rozedrgany”, „załzawiony dźwięk”).

\section{Liryczne opisy percepcji}

Opisując własne doznania audialne, autor relacji stosuje animizacje i personifikacje („Szaleje, krzyczy w basie”, „I nagle się rozpłakał po klawiszach sztajer”). Używa metafor, będących „najczęstszym środkiem wyrazu, jak również nieustającym źródłem nieporozumień, w opisie oraz w zrozumieniu dzieła muzycznego"27. Tworzy liryczne obrazy, które można traktować jako powstałe w czasie słuchania skojarzenia przymuzyczne i skojarzenia pozamuzyczne, które rozwijają się, co prawda, pod wpływem muzyki, ale rozprzestrzeniają się na inne, niż muzyczne, sfery wyobrażeń. Powstałe w ten sposób skojarzenia, odsyłające do konkretnych osób, rzeczy, sytuacji życiowych czy zdarzeń, chociaż wywodzą się z utworu muzycznego, to „wiążą się z nim dowolnie, subiektywnie i opacznie”28. Stan uczuciowy i wzruszeniowy, jaki owładnął podmiotem słuchającym w wierszu Mochnacki, dość szybko przestaje być tylko bezpośrednią emocjonalną reakcją na słyszany utwór, a staje się oddzielnym, samorodnym i samowolnym procesem uczuciowo-wzruszeniowym, który rozwija się w nim jedynie na tle danego utworu, a nie w ścisłym, rzeczowym i ciągłym uzależnieniu od niego ${ }^{29}$.

Podmiot słuchający w wierszu Mochnacki - pod wpływem muzyki - przebywa w świecie własnych uczuć i wzruszeń, rodzących się przy akompaniamencie kompozycji, powstających niejako obok dźwięków, a nie w świecie muzyki. W czasie koncertu - korzystam ze sformułowań Stefana Szumana, opisującego stan wielu słuchaczy - „zwidują mu się i przesuwają przed oczyma jego wyobraźni różne obrazy i sceny - jak w śnie. [...] Zlewają się one ze słyszanym utworem muzycznym w jedną całość i towarzyszą mu jakby «programowy» tekst. Powstaje wówczas jakby parafraza niewyrażalnego sensu danego utworu muzycznego"30.

27 M. Szyszkowska, Metafora w doświadczeniu dzieła muzycznego. Wokół koncepcji Rogera Scrutona, „Sztuka i Filozofia” 2008, nr 32, s. 27.

28 S. Szuman, dz. cyt., s. 61.

29 Korzystam ze sformułowań Stefana Szumana, dz. cyt., s. 35.

30 S. Szuman, dz. cyt., s. 56. 
Słuchana melodia zdaje się tylko pretekstem do tworzenia poetyckiej wizji ${ }^{31}$. Ważniejszy od programu koncertu jest stan uczuciowy, jaki owładnął słuchaczem. Dlatego relacja „nie składa się z konkretnych, znanych również w rzeczywistości pozaliterackiej utworów muzycznych, ale jest improwizacją przypominająca wielkie improwizacje romantyczne" 32 .

Wewnętrzne obrazy, aktywizujące się u słuchaczy podczas odbioru muzyki, jeszcze na początku XX wieku postrzegano jako znak doskonałości utworu. Zwolennicy subiektywistycznej koncepcji treści muzycznej uznawali zdolność do oddawania muzyką własnych emocji i przeżyć za najważniejszą właściwość stylu największych: Ludwika van Beethovena i Wolfganga Amadeusza Mozarta, Fryderyka Chopina. Dopiero kilkadziesiąt lat później uczucia wzbudzane przez muzykę zaczęto traktować jak balast utrudniający właściwy, czyli profesjonalny odbiór dzieła muzycznego. Uznano za nieprofesjonalnego takiego słuchacza, który posiada „silną pobudliwość wewnętrzną, oczekującą tylko jakiegokolwiek impulsu z zewnątrz, aby wysublimować się i wcielić w doznanie psychiczne, przy braku doświadczenia uznawane za przeżycie estetyczne związane z muzykąa"33. Słuchacza, który rzadko zdaje sobie sprawę z własnych mankamentów i tworzy „skojarzenia dźwiękowo-naśladowcze, albo podkłada pod muzykę własne treści psychiczne" ${ }^{\text {"34 }}$, zestawiono z słuchaczem doskonałym, posiadającym „dostateczne kwalifikacje, by bez reszty zdać sobie sprawę z systemu organizacji dźwięku zawartego w utworze, i umiejącym przetransponować tę swoją świadomość na język emocji czysto muzycznej"35.

Współcześnie muzyka traktowana jest jako sztuka asemantyczna, która poza wywoływaniem pewnych stanów uczuciowych i wzruszeń psychiki - nie przedstawia i nie sugeruje nic poza tym, co konkretnie i bezpośrednio słuchowi podaje $^{36}$. Do odejścia od koncepcji autonomicznego, czysto muzycznego przeżycia estetycznego w pewnej mierze przyczynili się, wskazał Stefan Kisielewski, sami twórcy muzyczni,

którzy w pewnych okresach (romantyzm, neoromantyzm, weryzm, impresjonizm) zapragnęli powiązać muzykę z emocjami natury pozamuzycznej, uczuciowej czy - jak impresjoniści - optycznej, emocjami nazywanymi po imieniu, wskazanymi

31 O programie koncertu Mochnackiego, który odbył się 23 marca 1832 w Metzu, pisał m.in.

R. Loth, dz. cyt.

32 Por. tamże, s. XLI.

33 S. Kisielewski, Muzyka i mózg, w: tenże, Pisma i felietony muzyczne. T. 2, wstęp A. Wiatr, Wydawnictwo Prószyński i Ska, Warszawa 2012, s. 318.

34 Tamże, s. 319.

35 Tamże, s. 318.

36 S. Szuman, dz. cyt., s. 55. 
wprost, nawet w tytule; łączy się z tym oczywiście rozkwit opery Wagnerowskiej i jej ideałów „syntezy sztuk”37.

U schyłku XIX wieku - niezależnie od prób pogodzenia romantycznej estetyki z klasycyzującą koncepcją harmonii treści i formy - starano się uściślić tezy o obrazowej treści muzyki, ustalić, „co konkretnie «wyraża» muzyka, w jaki sposób dzieło muzyczne zostaje wyposażone w treść, jaki jest status ontologiczny owej treści oraz jak poznaje ją słuchacz"38. Wówczas najważniejsze pojęcia o istocie ontologicznej i sensie muzyki kształtowała między innymi idealistyczna koncepcja wczesnych romantyków, zakładająca że muzyka jest samym czuciem. Od romantyków przyjęto założenie, że muzyka jest tworem idealnym, wyposażonym przez twórcę w przekaz transcendentny, który rozszyfrowywany zostaje przez uczucia, będące często postrzegane jako treść samej muzyki ${ }^{39}$. Dlatego „wczuwanie się” uchodziło w tej epoce za optymalny sposób odbioru muzyki ${ }^{40}$. Tym bardziej, że percepcję utworu muzycznego postrzegano w kategoriach dialogu; i to było Lechoniowi szczególnie bliskie. Po pierwsze, dialogu prowadzonego przez słuchacza z kompozytorem, polegającego na identyfikacji z przesłaniem dzieła, przyjęciu idei i uczuć zawartych w utworze, a po drugie, dialogu prowadzonego przez muzyka ze zbiorowością, której przeżycia potrafił on wyczuć, a następnie wyrazić ${ }^{41}$.

Poszukiwanie konkretnych znaczeń formuł muzycznych, po zawieszeniu granic między poezją a muzyką, uprawomocniły również nowatorskie rozwiązania stosowane w dramacie Wagnerowskim. Stąd też w tamtym okresie niestrudzenie powielano „romantyczny wzorzec opisu ballad, a także sonat Chopina jako historii wojennych, związanych z walką narodu polskiego z rozmaitymi wrogami z realnej lub mitycznej przeszłości”42.

Poglądy estetyczne Jana Lechonia - zrekonstruowane w oparciu o ujawniony w wierszu Mochnacki sposób odbioru utworu muzycznego - wpisują się w dyskurs krytyczno-muzyczny prowadzony na przełomie XIX i XX wieku. Są one zbieżne ze sposobem słuchania właściwym dla romantyków, których muzyka wprowadzała

37 S. Kisielewski, dz. cyt., s. 317.

38 Por. M. Dziadek, Polska krytyka muzyczna w latach 1890-1914. Koncepcje i zagadnienia, Wydawnictwo Uniwersytetu Śląskiego, Katowice 2002, s. 134.

39 Według Zygmunta Noskowskiego, muzyka wpada „wprost do duszy, bez uciekania się o pomoc do wyobraźni czy rozumu. Żadnej drogi pośredniej tu nie trzeba". Z. Noskowski, Istota utworów Chopina, „Wędrowiec”1900, nr 27, s. 528.

40 Por. M. Dziadek, dz. cyt., s. 136.

41 Wysunięto nawet tezę „o tożsamości zakodowanych w dziele przeżyć i uczuć artysty z przeżyciami zbiorowymi, jakie są udziałem pewnej formacji społecznej czy - w skrajnych przypadkach - ludzkości, została zobrazowana w postaci charakterystycznej metafory przedstawiającej Beethovena jako cierpiącego w imię całej ludzkości czy za ludzkość Prometeusza". Tamże, s. 142. Tamże, s. 145. 
w stan marzenia, ułatwiając napływ obrazów, będących jakby komentarzem do sztuki dźwięku ${ }^{43}$.

Przyjmując założenie współczesnych psychologów, że na percepcję muzyki mają wpływ wcześniejsze doświadczenia słuchacza, jego nawyki percepcyjne, uzdolnienia, kompetencje muzyczne, szeroko rozumiana wiedza muzyczna oraz cechy duchowo-intelektualne, należy wziąć również pod uwagę biografię poety. Warto dodać, że nie tylko współcześnie, ale także w epoce poprzedzającej powstanie wiersza Lechonia, twierdzono, że jedynie słuchacz posiadający szeroki wachlarz umiejętności zdolny jest do pełnego, estetycznego przeżywania muzyki. Taki odbiór wymaga bowiem zaangażowania zarówno czynnika emocjonalnego, jak i czynnika intelektualnego; współdziałania, które „pomaga porządkować w świadomości słyszaną muzykę, dostrzegać ład w jej organizacji”44. Na początku XX stulecia owe naukowe sposoby śledzenia konstrukcji utworu nie były traktowane jako coś gorszego; były dopuszczalne.

\section{Tradycja romantyczna}

Na sposób odbioru muzyki przez Leszka Serafinowicza niewątpliwie wpłynęły jego zainteresowania artystyczne i doświadczenia percepcyjne nabyte w dzieciństwie.

W wieku siedmiu lat nie tylko umiał płynie czytać, lecz także przejawiał uzdolnienia wokalne, śpiewał razem z kolegą Stasiem Balińskim w chórze kościelnym. Bywał z matką i rodzeństwem w teatrach, galeriach oraz muzeach [...]. Uwrażliwiony od dzieciństwa na sztukę będzie po latach wspominał wizyty w Zachęcie, bohaterów płócien Wojciecha Kossaka, „ułana z kowalową”, „surrealistyczne fantazje” Jacka Malczewskiego, obrazy Wyczółkowskiego, „śniegi Fałata»45.

Doświadczenia artystyczne Lechonia w głównej mierze formowała atmosfera domu rodzinnego zależna od tradycji niepodległościowej, kultywowanej przez Marię i Władysława Serafinowiczów, rodziców przyszłego poety ${ }^{46}$. Dla Lechonia poezja romantyczna była „czymś bardzo bliskim, powietrzem którym [...] oddychał od młodości. Kształtowała ona nie tylko jego świadomość ludzką, ale także nadawała znaczące piętno jego tekstom własnym"47. Formowała go również, jako miłośnika teatru, który „tworzył podług bardzo dobrze znanych wzorców”48, czerpiąc z twór-

43 Za: T. Makowiecki, Poezja a muzyka, w: tenże, Muzyka w twórczości Wyspiańskiego, Towarzystwo Naukowe, Toruń 1955, s. 11.

44 E. Szubertowska, dz. cyt., s. 15.

45 L. Sadkowska-Mokkas, Warszawa Skamandrytów, Bellona, Warszawa 2016, s. 26.

46 J. Lechoń, Dziennik. T. 3, Nakł. „Wiadomości”, Londyn 1973, S. 53.

47 M. Dąbrowski, Lechoń w sporze z romantyzmem, „Przegląd Humanistyczny” 1980, nr 1, s. 65.

48 J. Iwaszkiewicz, Lechoń i Tuwim, w: tenże, Książka moich wspomnień, Wydawnictwo Literackie, Kraków 1957, s. 337-340. 
czości Adama Mickiewicza, Juliusza Słowackiego i Stanisława Wyspiańskiego ${ }^{49}$. Tradycja romantyczna miała też wpływ na jego podejście do sztuki dźwięku. Lechoń, słuchając muzyki, pragnął przede wszystkim - tak jak Mickiewicz -

dotrzeć w przeszłość, wybiec w przyszłość, przeniknąć tajemnicę metafizyki [...]. Pieśń Wajdeloty, gra Jankiela budzić mają wspomnienia, przemawiać do sumień, do uczuć słuchaczy; symbolem pamięci kulturowej jest „pieśń gminna”, czyli połączenie słowa i dźwięku - literatury i muzyki. Halban śpiewa, w istocie, o tym, co sam robi: o przywoływaniu w „pieśni” przeszłości po to, by obudzić pamięć o niej ${ }^{50}$.

Stąd też słowna relacja z koncertu Mochnackiego nasycona owymi skojarzeniami przymuzycznymi i pozamuzycznymi, przede wszystkim iskrzy się obrazami dawnych dziejów, za pomocą których poeta dokonuje rozrachunku z przeszłością. W odczuciu czytelników współczesnych Lechoniowi, Karmazynowy poemat był „zbiorem wierszy wyrażających nastroje związane z momentem odzyskania przez Polskę niepodległości” ${ }^{1}$, „wielką dyskusją o Polsce, o historii i tradycji, z którą odrodzona ojczyzna wkraczała w niepodległy byt, [...] polemiczną postawą wobec wielu mitów narodowych stworzonych przez romantyzm i utrwalonych w świadomości zbiorowej" ${ }^{52}$.

Dyskusją, będącą dialogiem dostrzeżonym i wyróżnionym przez romantyków, sposobem porozumienia między artystą a zbiorowością, której odczucia był on w stanie odczytać, a następnie poprzez sztukę wyrazić. Lechoń podzielał wszakże

49 Por. np. K. Wierzyński, O poezji Lechonia, w: S. Baliński i inni, dz. cyt, s. 6o; M. Tatara, Od poezji wieszczej do stereotypu, w: tenże, Dziedzictwo Słowackiego w poezji polskiej ostatniego półwiecza 1918-1968, Zakład Narodowy im. Ossolińskich, Wrocław 1973, s. 282-283; A. Kamieńska, Spektakl narodowy na małej scenie, „Życie Literackie” 1974, nr 2, s. 7; A. Hutnikiewicz, Jan Lechoń, w: Obraz literatury polskiej XIX i XX w. Literatura polska w okresie międzywojennym. T. 2, red. J. Kądziela, J. Kwiatkowski, I. Wyczańska, Wydawnictwo Literackie, Kraków 1979, s. 159-161; R. Matuszewski, Posłowie. Lechoń - poeta i człowiek, w: J. Lechoń, Poezje, wybór W. Nowakowska, Czytelnik, Warszawa 1987, s. 221-230; G. Ostasz, Od Tyrteuszy legionowych do „Herostratesa”, w: tenże, W cieniu..., s. 17-59; G. Ostasz, Wyspiański w recepcji skamandrytów, w: Wyspiański. Sesja naukowa, red. Z. Lisowski, Towarzystwo Literackie im. A. Mickiewicza, Siedlce 2001, s. 451-469; M. Sadlik, Skamandryckie zmagania ze spuścizną literacka Wyspiańskiego. Lechoń, Słonimski, Wierzyński, „Pamiętnik Literacki” 2003, r. 94, z. 4, s. 65-81; G. Ostasz, Mickiewicz w recepcji skamandrytów, w: Adam Mickiewicz. Dwa wieki kultury polskiej, red. K. Maciąg, M. Stanisz, Wydawnictwo Uniwersytetu Rzeszowskiego, Rzeszów 2007, s. 469-477.

50 M. Cieśla-Korytowska, Romantyczne przechadzki pograniczem, Universitas, Kraków 2004, S. $10-11,13$.

51 R. Matuszewski, dz. cyt., s. 223.

52 W. Smaszcz, Posłowie. Jan Lechoń - poezja, życie i śmierć, w: J. Lechoń, Poezje, Łuk, Białystok 1994, s. 143. 
przekonania krytyków muzycznych, którzy na przełomie wieków przyjęli koncepcje psychologicznej i obrazowej (literackiej) treści muzyki. Wrażenia, wzbudzane przez utwór muzyczny, traktuje podobnie jak oni, czyli jako własność „wykreowanego przez odbiorcę bohatera lirycznego" ${ }^{33}$. Bohatera, którego krytycy tamtej epoki naznaczyli cechami typowo romantycznymi, wiążąc tym samym piękno muzyczne z kluczową kategorią XIX-wiecznej estetyki muzycznej: ze wzniosłością, a także z innymi typowo romantycznymi kategoriami: oryginalnością i indywidualnością ${ }^{54}$. Dlatego bohater liryczny opisujący wydarzenia „dziejące się" w Mochnackim, również jest bliski

naturze wieszczemu „ja” lirycznemu romantyzmu [...] i posługuje się techniką wizji, której źródeł można się doszukiwać w tejże tradycji. Ta technika powołuje obrazy nie zawsze i nie w pełni ze sobą spójne, ich rozwojem i następstwem rządzi - jeśli to tak określić można - logika emocji, nie prawa świata przedstawionego. Obraz poetycki staje się w takim ujęciu nieprzekładalny - lub nie w pełni przekładalny - na język zracjonalizowanego dyskursu ${ }^{55}$.

Badając wpływ wcześniejszych doświadczeń Lechonia na późniejszy jego sposób słuchania sztuki dźwięku, należy dodać, że tworząc poetyckie wizje muzyki posługiwał się on techniką wizji, mającą swe źródła w jego „świetnej znajomości malarstwa i fascynacji teatrem ${ }^{56}$. Stąd też „w służbę swego wiersza wprzągł nie tylko dźwięk melodyjny, ale także wizję malarską i gest sceniczny" ${ }^{37}$. W wyniku czego relacja $\mathrm{z}$ koncertu Mochnackiego „wciąga nas w akt stawania się duchowego dramatu [...], ukazująca improwizację pianisty, wbrew faktom, lecz zgodnie $\mathrm{z}$ tradycją romantyczną, która w seansie improwizatorskim widziała najwyższy akt twórczy i spontaniczny wyraz natchnienia" 58 .

Poznajemy nie tylko przebieg koncertu, jaki miał miejsce w 1832 roku w Metzu, ale uczestniczymy - nawiązując, jako czytelnicy, rzekomy dialog z Lechoniem - w „akcie stawania się" dramatu romantycznego; a równocześnie - tworzenia się spektaklu modernistycznego, „teatru ogromnego” - rodem z twórczości Wyspiańskiego, którego autor Cudownego świata teatru cenił bardzo wysoko ${ }^{59}$.

53 Por. M. Dziadek, dz. cyt., s. 135.

54 Tamże.

55 R. Loth, dz. cyt., s. XLVI

56 Obrazek sceniczny W noc jesienna, z rolą Maurycego Mochnackiego, Lechoń napisał w roku 1915, kiedy był jeszcze uczniem szkoły im. Emiliana Konopczyńskiego. Za: W. Smaszcz, dz. cyt., s. 137.

57 Por. J. Kwiatkowski, dz. cyt., s. 18-19.

58 D. Utracka, dz. cyt., s. 566.

59 Por. J. Lechoń, Cudowny świat teatru. Artykuły i recenzje 1916-1962, oprac. S. Kaszyński, Państwowy Instytut Wydawniczy, Warszawa 1981. 
Percepcja rzeczywistości fonicznej prezentowana w wierszu Mochnacki ujawnia stosunek Jana Lechonia do rzeczywistości pozaliterackiej. W wyniku dokonanej przez słuchacza selekcji poznajemy przestrzeń dźwiękową nasyconą wybranymi odgłosami oraz nutami koncertu Mochnackiego. W centrum uwagi „nausznego świadka" usytuowane są zdarzenia dźwiękowe poświadczające iście romantyczną pozycje artysty, natchnionego muzyka, dokonującego rozrachunku z przeszłością i wieszczącego przyszłość.

Poeta odnotowuje w wierszu zaistnienie konkretnych dźwięków, ale ważniejszy jest dla niego zapis powstałych pod wpływem muzyki wyobrażeń, obrazów inicjowanych melodią, skojarzeń pozamuzycznych i przymuzycznych. Wcześniejsze doświadczenia Lechonia oraz kompetencje i wrażliwość muzyczna podmiotu słuchającego decydują o tym, że to tradycja romantyczna kształtuje jego wyobraźnię i sposób słuchania muzyki, a zarazem współtworzy mentalny obraz rzeczywistości.

\section{Bibliografia}

Balcerzan Edward, Poezja jako semiotyka sztuki, w: Pogranicza i korespondencje sztuk. Studia, redakcja Teresa Cieślikowska, Janusz Sławiński, Wydawnictwo Instytutu Badań Literackich PAN, Wrocław 1980, s. 11-38.

Baliński Stanisław i inni, Pamięci Jana Lechonia, Nakł. „Wiadomości”, Londyn 1958.

Burek Tomasz, Wstęp, w: Jan Lechoń, Poezje wybrane, wybór i wstęp T. Burek, Ludowa Spółdzielnia Wydawnicza, Warszawa 1990, s. 5-20.

Chyła-Szypułowa Irena, Muzyka w poezji Jana Lechonia, „Studia Artystyczne Akademii Świętokrzyskiej" 2007, t. 4, s. 13-23.

Cieśla-Korytowska Maria, Romantyczne przechadzki pograniczem, Universitas, Kraków 2004.

Dąbrowski Mieczysław, Lechoń w sporze z romantyzmem, „Przegląd Humanistyczny" 1980 , t. 24, nr 1, s. 63-75.

Dziadek Magdalena, Polska krytyka muzyczna w latach 1890-1914. Koncepcje i zagadnienia, Wydawnictwo Uniwersytetu Śląskiego, Katowice 2002.

Gradowski Mariusz, R. Murray Schafer - pan od przyrody?, „Glissando” 2004, nr 2, s. 27-35.

Grygar Mojmir, Struktura prozy epickiej a jej stosunek do rzeczywistości, w: Styl $i$ kompozycja. Konferencje teoretycznoliterackie $w$ Toruniu $i$ Ustroniu, red. Jan Trzynadlowski, Zakład Narodowy im. Ossolińskich, Wrocław 1965, s. 189-201. 
Hejmej Andrzej, Muzyczność dzieła literackiego, Wydawnictwo Uniwersytetu Wrocławskiego, Wrocław 2001.

Horzyca Wilam, „Karmazynowy poemat”, „Skamander” 1920, z. 3, s. 159-170.

Hutnikiewicz Artur, Jan Lechoń, w: Obraz literatury polskiej XIX i XX w. Literatura polska w okresie międzywojennym. T. 2, red. Jerzy Kądziela, Jerzy Kwiatkowski, Irena Wyczańska, Wydawnictwo Literackie, Kraków 1979, s. 159-161.

Iwaszkiewicz Jarosław, Lechoń i Tuwim, w: Książka moich wspomnień, Wydawnictwo Literackie, Kraków 1957, s. 337-340.

Jorasz Urszula, Selektywność układu słuchowego, Wydawnictwo Naukowe UAM, Poznań 1999.

Jorasz Urszula, Wykłady z psychoakustyki, Wydawnictwo Naukowe UAM, Poznań 1998. Kamieńska Anna, Spektakl narodowy na małej scenie, „Życie Literackie” 1974, r. 24, nr 2, s. 7.

Kapelański Maksymilian, Koncepcja pejzażu dźwiękowego (soundscape) w pismach R. Murraya Schafera, praca magisterska, Warszawa 1999, https://static.squarespace.com/static/50b19a2ae4b01c11f0ef421b/t/51439234e4b0d8ae 42620f76/1363382836313/M.\%20Kapelanski\%20-\%20Pisma\%20Schafera.pdf, [dostęp: 2.02.2017].

Kisielewski Stefan, Pisma i felietony muzyczne. T. 2, wstęp Adam Wiatr, Wydawnictwo Prószyński i Ska, Warszawa 2012.

Kładoczny Piotr, Semantyka nazw dźwięków w języku polskim. T.1, Leksem, Łask 2012.

Kotliński Andrzej, Polonez artyleryjski Jana Lechonia, w: Reinterpretacje, red. Maciej Tramer, Agnieszka Wójtowicz, Wydawnictwo Uniwersytetu Śląskiego, Katowice 2015, s. 151-165.

Kultura dźwięku. Teksty o muzyce nowoczesnej, red. Christoph Cox, Daniel Warner, Wydawnictwo słowo/obraz terytoria, Gdańsk 2010.

Kwiatkowski Jerzy, Czerwone i czarne. O poezji Jana Lechonia, w: Jerzy Kwiatkowski, Szkice do portretów, Państwowy Instytut Wydawniczy, Warszawa 1960, s. 5-209.

Lechoń Jan, Cudowny świat teatru. Artykuły recenzje 1916-1962, oprac. Stanisław Kaszyński, Państwowy Instytut Wydawniczy, Warszawa 1981.

Lechoń Jan, Dziennik. T. 3, Nakł. „Wiadomości”, Londyn 1973.

Losiak Robert, O opisach pejzaży dźwiękowych, „Prace Kulturoznawcze” 2010, t. 9, s. 224-232.

Loth Roman, Wstęp, w: Jan Lechoń, Poezje, Zakład Narodowy im. Ossolińskich, Wrocław 1990, s. III-XCIV.

Makowiecki Tadeusz, Muzyka w twórczości Wyspiańskiego, Towarzystwo Naukowe, Toruń 1955.

Marciniak Krzysztof, Pejzaż dźwiękowy „Opisu obyczajów za panowania Augusta III” Jędrzeja Kitowicza, „Muzyka” 2014, r. 59, nr 1, s. 25-37.

Marciniak Krzysztof, Trzydzieści lat ekologii akustycznej w Polsce, „Ruch Muzyczny” 2012, nr 18, s. 11-15. 
Matuszewski Ryszard, Posłowie. Lechoń - poeta i człowiek, w: Jan Lechoń, Poezje, wybór Wanda Nowakowska, Czytelnik, Warszawa 1987, s. 221-230.

Misiak Tomasz, W stronę kulturoznawczych badań nad dźwiękiem, „Muzyka” 2014, r. 59, nr 1, s. 7-24.

Noskowski Zygmunt, Istota utworów Chopina, „Wędrowiec”1900, r. 38, nr 27, s. 528.

Opacki Ireneusz, Dramat narodowej wyobraźni. Wokół „Karmazynowego poematu” Jana Lechonia, w: Ireneusz Opacki, Poetyckie dialogi z kontekstem. Szkice o poezji XX wieku, Wydawnictwo Śląsk, Katowice 1979, s. 155-224.

Opacki Ireneusz, Od „Karmazynowego poematu” do „Wolności tragicznej”. (Problematyka mitów narodowych w poezji Skamandra - zarys), w: Studia romantyczne, red. Ireneusz Opacki, Uniwersytet Śląski, Katowice 1978, s. 5-36.

Ostasz Gustaw, Bekwark. Jana Lechonia osobowy znak sztuki idealnej, w: Gustaw Ostasz, Śladami poezji czystej, Wydawnictwo Oświatowe Fosze, Rzeszów 2017, s. 39-52.

Ostasz Gustaw, „Marsz Drugiego Korpusu” Jana Lechonia, czyli „Jeszcze Polska nie zginęła”, w: Gustaw Ostasz, Filiacje, dialogi, spór z tradycja. Szkice o literaturze polskiej XX wieku, Wydawnictwo WSP, Rzeszów 2001, s. 65-79.

Ostasz Gustaw, Mickiewicz w recepcji skamandrytów, w: Adam Mickiewicz. Dwa wieku kultury polskiej, red. Kazimierz Maciąg, Marek Stanisz, Wydawnictwo Uniwersytetu Rzeszowskiego, Rzeszów 2007, s. 469-477.

Ostasz Gustaw, Od Tyrteuszy legionowych do „Herostratesa”, w: Gustaw Ostasz, W cieniu „Herostratesa”. O tradycjach romantyzmu w poezji polskiej lat 1914-1939, Wydawnictwo WSP, Rzeszów 1994, s. 17-59.

Ostasz Gustaw, Przypowieść Jana Lechonia, w: Gustaw Ostasz, „Przeciwko smokom, jadom, kulom... O poezji polskiej 1939-1945, Wydawnictwo WSP, Rzeszów 1998, s. 99-110.

Ostasz Gustaw, Wyspiański w recepcji skamandrytów w: Wyspiański. Sesja naukowa, red. Zbigniew Lisowski, Towarzystwo Literackie im. Adama Mickiewicza, Siedlce 2001, s. 451-469.

Radion Ewelina, Audiosfera „Karmazynowego poematu” Jana Lechonia, w: Literatura współczesna w edukacji polonistycznej. T. 2, Interpretacje - wartości - konteksty, red. Urszula Kopeć, Wydawnictwo Uniwersytetu Rzeszowskiego, Rzeszów 2017, s. $135-148$.

Sadkowska-Mokkas Lidia, Warszawa Skamandrytów, Bellona, Warszawa 2016.

Sadlik Magdalena, Skamandryckie zmagania ze spuścizna literacka Wyspiańskiego. Lechoń, Słonimski, Wierzyński, „Pamiętnik Literacki” 2003, r. 94, z. 4, s. 65-81.

Schafer R. Murray, Muzyka środowiska, tł. Danuta Gwizdalanka, „Res Facta” 1982, nr 9, s. 288-315.

Schafer R. Murray, The Thinking Ear. Complete Writings on Music Education, Arcana Editions, Toronto 1986. [Schafer R. Murray, Poznaj dźwięk. 100 ćwiczeń w stuchaniu i tworzeniu muzyki, przeł. Rafał Augustyn, Brevis, Poznań 1995]. 
Skarbowski Jerzy, Muzyczna dusza Jana Lechonia, „ISME” 1995, nr 3-4, s. 71-80.

Smaszcz Waldemar, Posłowie. Jan Lechoń - poezja, życie i śmierć, w: Jan Lechoń, Poezje, Łuk, Białystok 1994, s. 133-151.

Szubertowska Elżbieta, Muzyczna aktywność własna a świadoma percepcja muzyki młodzieży szkót średnich, Wydawnictwo Akademii Bydgoskiej, Bydgoszcz 2002.

Szuman Stefan, Zofia Lissa, Jak słuchać muzyki, Centralny Instytut Muzyki, Warszawa 1948.

Szyszkowska Małgorzata, Metafora $w$ doświadczeniu dzieła muzycznego. Wokół koncepcji Rogera Scrutona, „Sztuka i Filozofia” 2008, nr 32, s. 27-40.

Tatara Marian, Dziedzictwo Słowackiego w poezji polskiej ostatniego półwiecza 1918-1968, Zakład Narodowy im. Ossolińskich, Wrocław 1973.

Utracka Dorota, Emigracyjna wspólnota tęsknot, trosk i nadziei, czyli nad „koncertami polskości - Mickiewicz - Lechoń - (szkic analityczno-porównawczy), w: Szczególne problemy człowieka i edukacji u progu XXI w. Księga jubileuszowa ofiarowana Profesorowi Bogdanowi Snochowi, red. Stanisław Podobiński, Wydawnictwo WSP, Częstochowa 2002, s. 563-576.

Wierszyłowski Jan, Psychologia muzyki, Państwowe Wydawnictwo Naukowe, Warszawa 1979.

Wiśniewski Jerzy, Czy Maurycy Mochnacki koncertował, grając na klawikordzie? Uwagi na marginesie wiersza Jana Lechonia, „Acta Universitatis Lodziensis. Folia Litteraria Polonica" 2001, z. 2, s. 41-46.

Wiśniewski Jerzy, Ku harmonii? Poetyckie style stuchania muzyki w wierszach polskich autorów po 1945 roku, Wydawnictwo Uniwersytetu Łódzkiego, Łódź 2013.

\section{Percepcja wrażeń akustycznych w wierszu Mochnacki Jana Lechonia}

\section{Streszczenie}

Kontekstem prowadzonych badań nad percepcją rzeczywistości fonicznej prezentowanej w wierszu Mochnacki Jana Lechonia są interdyscyplinarne badania nad dźwiękiem (sound studies). Korzystam z ustaleń muzykologów, krytyków muzycznych, psychologów muzyki, psychoakustyków oraz literaturoznawców.

Postrzegam osobę mówiącą w kategorii Schaferowskiego „nausznego świadka”, werbalizującego swoje przeżycia w mowie wiązanej. Analizując liryczny opis per- 
cepcji, biorę pod uwagę zarówno reakcje na pojedyncze dźwięki, jak i wewnętrzne obrazy, aktywizujące się podczas słuchania muzyki.

Percepcja rzeczywistości akustycznej prezentowana $\mathrm{w}$ omawianym wierszu ujawnia nie tylko stosunek poety do sztuki dźwięku, ale również do rzeczywistości pozaliterackiej, a nade wszystko do tradycji romantycznej.

Słowa kluczowe: dźwięk, percepcja, słuchacz, romantyzm, improwizacja

\title{
The Perception of Sound Impression in the Poem Mochnacki by Jan Lechoń
}

\author{
Summary
}

This research on the perception of phonic reality presented in Jan Lechon's poem Mochnacki is based on interdisciplinary sound studies, specifically the findings made by musicologists, music critics, music psychologists, psychoacoustcians and literature spcialists.

The author perceives the speaking persona as the Schaferean "ear witness" verbalizing his experience in metrical language. In her research on lyrical description of perception, the author takes into account both the response to individual sounds and internal images, which become active when one is listening to music.

The perception of phonic reality presentend in the poem reveals the poet's attitude to not only the art of sound, but also non-literary reality and, above all, to the Romantic tradition.

Keywords: Jan Lechoń, Sound, Perception, Listener, Romanticism, Improvisation

Ewelina Radion, absolwentka filologii polskiej w Wyższej Szkole Pedagogicznej w Rzeszowie i podyplomowych studiów komparatystycznych w Uniwersytecie Jagiellońskim. Autorka prac o polskiej poezji dwudziestowiecznej. 